\title{
Self-Identification in a Spanish barrio and a French banlieue: The Case of North African Second Generations
}

\author{
Cecilia Eseverri-Mayer ${ }^{1}$ \\ University Complutense of Madrid, Spain
}

\begin{abstract}
This comparative and qualitative research examines the types of ethnic, racial, religious, and social identification that NorthAfrican second generations adopted in a banlieue of Paris and a peripheral barrio of Madrid. Four types of self-identification were detected in the neighborhood of Les Bosquets (Paris) and three in the neighborhood of San Cristobal (Madrid). In Les Bosquets, isolation, Islamophobia and the relationships with the police give rise to a "reactive ethnicity"; a new conservative Islam gains many followers ("Muslim self-identification"); race appears for the first time as an element of self-identification ("indigenous selfidentification") and secularism has waned ("laïc selfidentification"). In San Cristóbal, a significant share still feels like immigrants ("immigrant identification"); a new SpanishMuslim generation ("hybrid self-identification") is born, and the most vulnerable youth adopt a conservative Islam while simultaneously developing a sense of "neighborhood pride" and identification with the working class ("neighborhood identification").
\end{abstract}

Keywords: Islam, Islamophobia, North African background, second generations, segregated neighborhoods, self-identification.

Understanding how children from a Muslim background living in disadvantaged areas have adapted to European countries like France and Spain is theoretically important and a key policy issue. Because children of the Muslim population in some French banlieues make up more than $76 \%$ of the total population (Tribalat, 2010), their fate is enormously essential to this country's future. Though in Spain the percentage is lower - 10\% in certain urban areas and between $15 \%$ and $19 \%$ for the either second or 1.5 generation (Gebhardt et al., 2007) institutional concern for their integration has increased since the terrorist attacks in 2004 and 2017, as it has in France since the massacre in 2015. Thus, understanding why some young people succeed, and others stagnate and how they deal with their own racial and religious identification, their family heritage, and mainstream culture is essential. These issues have become a matter of public discussion and scholarly research in the past few decades in many migrant-receiving countries (Alba \& Waters, 2011; Berry et al., 2006; Crul et al., 2012; Gurer, 2019; Portes \& Zhou, 1993).

The aim of the results presented in this paper ${ }^{2}$ is to fill a gap in the understanding of the complex and diverse forms of self-identification of Muslim youth in specific disadvantaged urban areas of Europe. A sample of 143 young people (between 18 and 25 years of age) of

\footnotetext{
${ }^{1}$ Corresponding Author E-Mail: ceciesev@ucm.es

${ }^{2}$ The findings presented in this paper are a result of three research projects undertaken between 2015 and 2019 with the support of three Grants related to the youth inclusion, prevention of violence and civic participation among youth from African Background in Paris and Madrid: LOCAL YOUTH project; CIVIL MUSLIM project and CIVIL PREVENT project.
} 
Maghreb origin and a Muslim tradition provides insight into the trends dominating the Parisian suburb of Les Bosquets (15,000 inhabitants) and the Madrid neighborhood of San Cristóbal (14,980 inhabitants). They also reveal their most innovative forms of self-identification and whether young Muslims are developing reactive ethnicities. These two neighborhoods are coping with the consequences of Europe's heightened urban inequality (Pikety, 2019) in terms of income and youth unemployment ${ }^{3}$. They differ, however, in four key aspects. One is the ethnic composition of their populations (in Les Bosques, the ethnic concentration is greater, with only $30 \%$ of the population being white). In contrast, in San Cristóbal, the native Spanish population comes to 59\%). A second is youth access to civic participation (the institutionalization of the civic and anti-racist movements in Les Bosquets contrasts with the tightly-knit network of associations in the San Cristóbal neighborhood). A third is the connection to, or isolation from, the city center, which in addition to slowing down the circulation of ideas and customs, also reduces institutional resources and educational employment opportunities while aggravating the discrimination and stigmatization of the population (Jencks \& Mayer, 1990). Les Bosquets (District 93 Seine-Saint-Denis), the setting of the Victor Hugo novel Les Misérables, is thirty-two kilometers from the city center, one and a half hours on public transport, while San Cristóbal is well-connected to the city center, the Puerta del Sol (15 minutes by underground). The fourth is the level of state funding. Les Bosquets has undergone a great deal of urban renovation following the urban uprisings of 2005-it now has a police station and a health and a youth center. However, since the 2008 economic crisis, San Cristóbal has seen nothing but cutbacks and a deterioration in housing and practically non-existent public services. The comparison between these two unique and specific areas will reveal differential aspects that are key to understanding how young people identify themselves today ${ }^{4}$.

As a Spanish-French researcher, I have been involved in the study of vulnerable youth with a North African background since the first urban riots in Paris in 2005 (Eseverri-Mayer, 2007). I spend considerable time in disadvantaged urban areas, both in Paris and Madrid (Eseverri-Mayer, 2015, 2017, 2019), which gave me the opportunity to compare these two realities and understand the sentiment and self-identification of vulnerable Muslim youth. In a world of rising anti-Muslim sentiment and extremism (both far right and Islamist), it is crucial to look at how stigmatized and poor youth are feeling in important cities such as Paris and Madrid. The broader implication of this research is to study unexplored urban contexts and focus on shifting self-identification, behavior and sense of belonging of those who are more marginalized. This clearly remains one of the most serious challenges facing ethnic minorities in the contemporary world.

\section{Literature Review: Shifting Self-identification of North African Second Generations}

Self-identification refers to the affective implication with a collective or social category that holds a specific heritage and set of values, beliefs, and customs (Bourdieu, 1979), thus allowing for the process through which meaning is given to a specific life project (Castells, 2005). Studying religious, ethnic, racial, and social self-identification in this way allows the process to be seen along with the results (Brubaker, 2001), thus showing all its complexity and ambivalences.

\footnotetext{
${ }^{3}$ Les Bosquets is home to the poorest families in the Ile de France, with an annual income of 16,760 Euros (compared to the national average of 25,044) and an unemployment rate eight points higher than average (16\%) (Institut d'Amenagement et d'Urbanisme, 2019). San Cristóbal is the third poorest neighborhood in Madrid, where income is 16,971 Euros, compared to the average of 26,409, and the unemployment rate 10 points higher than the regional average (21.74\%) (Ayuntamiento de Madrid, 2017).

${ }^{4}$ See Eseverri-Mayer (2019) for a detailed description of the Spanish and French context. This paper has given preference to the exposition of results on ethnic, religious and racial self-identification.
} 
The role of race, ethnicity, religion, and class as markers of differences among the migrant populations was rarely mentioned during the 1980s and 1990s both in France and Spain. At that time, economic integration bore fruit, and aspects of identity were either relegated to the private sphere or gradually abandoned as the majority culture got assimilated, as explained in the United States by Straight-line Assimilation Theory (Park \& Burgues, 1925).

However, economic change and massive unemployment during the 1980s led to the first urban riots and birth of the anti-racism movement, revealing new complex and contradictory outcomes for the North African second generations living in impoverished areas, as segmented assimilation theory pointed out in the US (Portes \& Rumbaut, 2001; Portes \& Zhou, 1993). French scholars started noticing a new identity and new Islam in the banlieues (Kepel, 1987; Khosrokhavar, 1998) and remarking on what European researchers would outline for years to come, which the decoupling of ethnic and religious identities among many young Muslims (Jacobson, 1997). Many young Muslim (re)discover Islam and express new personal piety differing from the ethnic heritage of their parents' generation (Jacobson, 2010; Mushaben, 2008).

European and international literature on the second generation concludes that most youths assimilated, acculturated, or integrated with the hope of belonging and participating in mainstream society (Alba \& Waters, 2011; Beaman, 2017; Berry et al., 2006; Crul \& Thomson, 2007). The majority of the second generation adhered to what Portes and Rumbaut (2001) identified as selective acculturation or Berry and Hou (2017) called integration: "the strategy when there is a desire to maintain heritage culture and identity and at the same time to engage with others outside the own group" (2017, p. 30). This kind of acculturation is followed by "assimilation" or "consonant acculturation" strategies, which occurs when there is "little or no desire to maintain heritage culture and identity, and to engage (even merge into) the larger society" (2017, p. 30). Separation and marginalization (or dissonant acculturation) represent a minority of the second generation in all the contexts studied.

However, this strategy of separation characterized by a strong desire to maintain heritage, culture and identity, and avoid engaging the larger society as much as possible, tends to occur in certain vulnerable neighborhoods (Portes \& Rumbaut, 2001; Wacquant, 2008). Comparative Integration Context Theory (Crul \& Mollenkopf, 2012; Crul \& Thomson, 2007) shows that varying political and cultural reactions to Muslims in Europe shape youths' identities. In the case of France, color-blind ideology (Beaman, 2017; Chacal, 2015; Keaton, 2010), rampant Islamophobia (Abdellali \& Mohammed, 2016) and the instrumentalization of the Muslim middle class by political parties (Wihtol de Wenden \& Leveau, 2001) in some banlieues gives rise to a "distinct community" and "distinct identity" concerning ethnic origins (Barwick \& Beaman, 2019; Chacal, 2015; Roy, 2009). The most recent French survey on second generation integration (Simon et al., 2018) and other case studies (Pégram, 2020) demonstrated that an important part of the second generation living in the suburbs do not identify themselves strongly with the majority culture or feel French only, although their connections to the heritage group remain strong.

Also, some researchers identify a new conservative Islam that has grown in popularity in certain banlieues, one offering a local and a global belonging through the umma - the universal community of believers (Mushaben, 2008). The youth learn new ethnic and community norms in the local mosques or online, a dynamic that is not just individual as happens in the middle classes (Beaman, 2017), but also collective and does not hinder identification with the French identity (Keaton, 2010), though a small segment is starting to reject outright the institutions of the Republic (Eseverri-Mayer, 2019) and develop a reactive ethnicity. This paper uses the definition of reactive ethnicity that Portes and Rumbaut (2001) proposed, meaning this kind of self-identification as an ethnic reaffirmation, increased peer solidarity, and susceptibility to racism. 
In Spain, the situation is different, and the research scarce. Portes et al. (2013, 2016, 2018) have confirmed the applicability of Segmented Assimilation Theory and discovered that the absence of strict assimilation guidelines and a powerful local policy might explain the second generation's positive attitude and identification with the Spanish identity. Also, previous research has allowed me to show how young people in Madrid have managed to develop a mixed or hybrid identity, due to reduced ethnic segregation and the positive processes of civic participation at the local level, (Eseverri-Mayer, 2015). For the moment, no development of a reactive identity has been observed; instead, a positive identification has been seen with the local space, with the social class concentrated in this neighborhood and with civic associations (Eseverri-Mayer, 2015, 2017; Téllez \& Madonia, 2018). However, in most cases, discrimination impacts the Northern African second generation, which might alter their positive belonging, as other researchers have noted in the region of Catalonia where the evolution of the new conservative Islam has been identified (Moreras, 2018).

Despite consensus among researchers about the positive assimilation of the North African second generation in Europe, this research has found a need for more detailed studies to specify how self-identification in disadvantaged urban areas intersect with race, class, ethnicity, and religion. The literature on second generations in France and Spain has primarily focused on religious aspects and the processes of economic and social integration, leaving aside any description of the types of self-identification in segregated places that, for example, Waters (1994) did with her study about the second generation in New York City. She observed three types of identity: 1) a Black American identity, typical among segregated youth who had no contact with whites and who tended to be critical of the "American dream," pointing out racial discrimination and a bleak future; 2) an ethnic identity that attempts to distance itself from the black underclass, extolling their community values and assimilating into the white American middle class; 3) and an immigrant identity that shows strong links with the country of origin.

Substantively, this paper aims to shed light on this complex new issue to enter into dialogue with this existing literature and make further strides in this field of study.

\section{Methodology}

The empirical results of this research are drawn from a qualitative methodology and an ethnographic approach, aiming to interpret the values, behaviors, beliefs as well as issues such as power, resistance, and dominance of vulnerable youth (Creswell, 2007; Denzin \& Lincoln, 2011). Between Autumn 2013 and Summer of 2019, I was able to carry out participant observation, 143 biographical interviews (Bertaux, 1980) and to implement the Touranian method of Sociological Intervention (SI). The objective was to compare and contrast share patterns of these two groups with a similar socioeconomic situation, and a common cultural and religious background in two European cities (Creswell, 2007).

The SI method stems from Touraine's $(1965,1978)$ Theory of Social Action, framed in the Weberian tradition. In it, a sociologist does not just observe but also intervenes in the field to learn youth experience and their capacity for action and innovation. This method consists of bringing 15 young participants together regularly (10 sessions over three months) to discuss key issues - education, security, politics, entrepreneurship, art, racism, and Islamophobiawith key speakers: a successful businessman, an artist of Maghreb origin, a teacher, two police officers, a local policymaker, an imam and a leader in the anti-racism or anti-Islamophobia movement. These "open" sessions were interspersed with "closed" sessions during which the previous discussions were analyzed, and the first categories of analysis were extracted, in the sense that Glaser and Strauss (1967) provided.

During the fieldwork, the participant observation was done by attending youth and educational centers, place of worship and I took part in cultural events, workshops, civic meetings, actions, protests etc, ... Being present for several months in each neighborhood 
allowed me to engage with young Muslims and gain their trust. Once I had their trust, it was easier to get them to take part in both techniques: SI and biographical interviews. Saturation was reached with a total sample of 143 participants (70 in Madrid and 73 in Paris), who were individually interviewed, 30 of whom $(15+15)$ were selected to participate in the SI sessions. Youth of the sample were between 18 to 25 years old and from a North African background (35 young women and 34 young men in Madrid, and 37 young men and 33 young women in Paris).

Table 1

Social Characteristics of the Sample

\begin{tabular}{|c|c|c|}
\hline & $\begin{array}{l}\text { San Cristóbal } \\
\text { (Madrid) }\end{array}$ & $\begin{array}{l}\text { Les Bosquets } \\
\text { (Paris) }\end{array}$ \\
\hline $2^{\circ}$ and $3^{\circ}$ generations & $43(62 \%)$ & $73(100 \%)$ \\
\hline Arrived before 5 & $5(7 \%)$ & 0 \\
\hline Arrived after 5 & $22(31 \%)$ & 0 \\
\hline Non-educated & $26(37 \%)$ & $9(12 \%)$ \\
\hline Professional studies ${ }^{5}$ & $24(34 \%)$ & $36(50 \%)$ \\
\hline High school & $20(2 \%)$ & $22(30 \%)$ \\
\hline University & 0 & $6(8 \%)$ \\
\hline Working ${ }^{6}$ & $36(51 \%)$ & $34(47 \%)$ \\
\hline $\begin{array}{l}\text { Neither studing not } \\
\text { working }^{7}\end{array}$ & $17(24 \%)$ & $8(10 \%)$ \\
\hline
\end{tabular}

Note. $\mathrm{N}=143$ (70 in San Cristóbal, 73 in Les Bosquets) Number of respondents (\%)

Being sensitive to vulnerable populations and imbalanced power relations, the consent, privacy and confidentiality of the participants were protected, and their oral expression and language respected in all the process of analysis and interpretation. A selection of the most illustrative quotations from the participants have been done in order to describe and classify their forms of self-identification.

Furthermore, this comparative and ethnographic research does not claim for an inductive validity in order to generalize these findings across other vulnerable neighborhoods of Madrid and Paris. However, this research is of interest as it captures youth' sentiments and values, both in a collective way (during the SI sessions and observations) and in an individual way (during the biographical interviews). This contrast allows to determine share patterns and also contradictions and ambivalences in their feelings of belonging and identification.

\section{Findings}

This study set out how young people self-identify to the ethnic and religious group; how they feel attached or separated to the mainstream society and how they belong to their place of living (and their social class). I could find four types of self-identification in Paris (Les Bosquets) and three in Madrid (San Cristóbal). In Paris, on the one side, I found that the majority (more than a half) of youths identify with a new conservative Islam and feel Muslim

\footnotetext{
${ }^{5}$ In Paris, the majority were studying to become managers, accountants, nursery schoolteachers and shop assistants. In San Cristóbal the majority were studying to become hairdressers, computer assistants, plumbers, etc. ${ }^{6}$ In San Cristobal, the majority were unskilled workers and in Paris (11\% out of $47 \%$ who are working) they are doing internships.

${ }^{7}$ Referring to young people who are not in education, employment or training (NEETs).
} 
before French. This is a very important change this research has found on self-identification in contrast to international and comparative research (Berry \& Hou, 2017; Crul et al., 2012; Drouhot \& Nee, 2019; Portes \& Rumbaut, 2001) and also French studies developed in the suburbs during the 80s, 90s and 2000s (Kepel, 1987; Khosrohavar, 1998; Roy, 2006). It confirms, thought, some of the most recent ethnographies and case studies about the most vulnerable banlieues (Barou, 2014; Eseverri-Mayer, 2019; Pégram, 2020). The group how still identify themselves as French and laïc become less important (a quarter of the sample) and they tend to be not comfortable with the previous group. On the other side, youth identifying as indigènes (post-colonial heirs) and engaged in political activism, reclaiming their racial and ethnic heritage, and those who reject and express an anger towards French identity represent a minority within this neighborhood.

On the contrary, in Madrid, the majority (half of the sample) defend that they have the right to feel Muslims and Spanish at the same time. This is very much in keeping with the findings of many Spanish studies (Madonia, 2018; Poster, et al., 2016; Tellez \& Madonia, 2018; Veredas, 2011). They defend a revision of some "archaic" traditions and do not feel discrimination as insurmountable barrier to their life plans and feelings of belonging. As in Paris, I have found a self-identification to a new conservative Islam, but in this case combined with a strong "feeling of neighborhood pride". Young people feel part of a poor social class, divers in terms of ethnicity and with a capacity for activism. This strong sense of belonging to the city and the neighborhood has been also identify in other European research (Barwick \& Beaman, 2019; Mythen, 2012; Simon et al, 2018). Lastly, immigrant self-identification and the attachment to the country of origins and its traditional Islam is still important in Madrid (31\% of the sample).

In some, this comparative research shows how race, religion and ethnicity shape selfidentification. But, above all, it demonstrates the determinant influence of four crucial variables: social class, Islamophobia and lack of ethnic diversity and civic participation. Its effects on the young people life's and self-identification will be illustrate by the typology presented below.

\section{Youths in the Banlieue of Les Bosquets: Between Laïc, Muslim, and Indigenous Self- identification and a Reactive Ethnicity}

\section{Laïc Self- identification, "à la française”}

Of the sample, 29\% (21 of 73 young people interviewed) identified with French secularism. When any member of their surroundings or family criticizes France or secularism, they oppose it. They define themselves as open-minded and heirs to the anti-racist struggle of the 1980s, progressive and left-wing, but against the new anti-Islamophobia movements. They acknowledge the existence of Islamophobia, especially after the 2015 attacks, but believe "communitarian" demands will fail to resolve the situation and indeed result in harmful victimhood. They maintain the need to break down barriers and transcend boundaries, leaving a neighborhood where only a very narrow vision of the world is available.

A conversation between a boy and a girl in the SI session discussing racism (with the leader of the "Collectif contre l'Islamophobie" as the speaker) illustrates this kind of ethnic and religious identification.

How do you feel? French, Maghreb, Muslim...?

I am tired of these kinds of questions. I'm French, I was born here, I can't feel how people from the Maghreb feel, and I don't feel Muslim. I belong to my group of friends, to my group of street dance. 
Yeah, me neither... I am French, and I want to fight to be a part of this society. You can't say, "this society is racist, and I just stay in my neighborhood doing nothing," "I am a victim, I am a victim." Now, we can go to the university.... It is true that it is more complicated for us to be hired in a law firm or be in charge. But, in my case, this injustice makes me want to continue fighting.

Most of these young people have at least one parent with human capital (education or social and personal skills acquired through experience). Just as in the process of "consonant acculturation," they build a relationship of cooperation with them, learn French culture and gradually abandon their home language and "old country" ways at about the same pace. They develop a symbolic ethnicity (Waters, 1990), accepting key traditions (Ramadan or Eid), but rejecting roles (wearing the hijab, praying five times per day, marrying a Muslim, or eating halal). They make a clear distinction between faith - believing in a spiritual sense, as a personal and private choice - and traditions - defined as conservative - and they agree with the law approved in 2004 about religious symbols in public schools. They differ from the young people who adopt a new ambivalent conservatism, and they denounce the control and the "Arab telephone" (gossip) in the neighborhood.

I think that many girls are real hypocrites because they want to be seen as "the best Muslims" and show French people that they are wrong about Muslims and fight Islamophobia, but at the same time, they judge other girls that have decided not to follow traditional norms. They're hypocrites because after gossiping, they hide when doing things that are forbidden (...) We are French, and we need to talk as if we were.

Therefore, they are young people who go out regularly to do leisure activities in the urban center, who have Jewish, Muslim, and Catholic friends, and who use their academic success as a vehicle for leaving the neighborhood and settling down in the cosmopolitan center of Paris.

\section{New Muslim Self-identification}

Approximately 53\% of the 73 respondents in the banlieue of Les Bosquets adopted a strong Muslim identification, stressing their ethnic origins and religious beliefs. The majority have parents with weak human and social capital and, even if they have done better than their parents at school - most have finished secondary school or are doing professional training-, their aspirations are in no way associated with a desire to go to university, travel or meet people with different interests or cultural background. They are instead related to getting a job, a home, staying in the area (District 93), marrying "not too old" (about 25-28) to a Muslim, and having children.

They are uninterested in politics, unlike the first group and the self-identified indigenous. Their disaffection concerning political parties stems from the Islamophobia of political speeches and its materialization in the 2004 Law on the prohibition of religious symbols and their rejection in the urban center.

If I lived in London, I would wear a veil, but here you take the tube, and people sneer at you. That they won't let a mother accompany her son on a school trip because she wears a veil is really unbelievable! That 
happened to my cousin!" (...) Islam is a way of life for me. It gives me security, it gives me peace, and it helps me overcome difficulties.

Most do not have friends from different ethnic and religious groups and rarely frequent the city center. They set themselves apart from the "secular youth" and develop a sense of belonging to the local and international (global) umma. For this reason, they distance themselves from the traditional Islam of their parents and proudly show off a new way of life, one that instills them with new confidence, giving them a reference point based on a conservatism learned on social networks and listening to imams with thousands of followers influenced by the more fundamentalist strains (Salafiya and Wahhabism) claiming to come from the most genuine tradition. Locally, most of them belong to or participate in the ACCEM association (where the mosque is located). Some of these youth volunteer at the mosque or work for one of the business associates of the UAM93, the federation of Muslim Associations in District 93. The effervesce of a new Islamic economy in the banlieues is linked to this new kind of "traditional identification." Young people find an alternative space for socio-economic integration. It remains to be seen whether this trend will continue in the coming years and the link to ethnic networks becomes a real way out for these young people.

During the SI, most of them justify and legitimize the patriarchy ("we are not equal, even if the French want us to be") and the prohibition against women marrying a non-Muslim ("If I fancy a French guy, I look the other way, I control myself. Marrying a non-Muslim means abandoning both Islam and your family"). Nor do they agree with the re-interpretation of the Koran (ijtihad) or the new Islamic feminism, and they are against gay marriage. Most are skeptical of scientific explanations that cite the origin of man in apes ("I can't believe we came from monkeys! That's a lie!").

However, despite their determination to choose to self-identify with conservative Islam, the tension during the SI sessions with the "secular youth" who accuse them of being "hypocrites" reveals a sense of unease that some explain during the biographical interviews. This is the case of a young man who, during the SI session with the imam, defended the need for a patriarchal system but then expressed in the interview his frustration at feeling the need to be the patriarch and provider of his family, anger at his inability to get a job and gain independence.

\section{Sometimes I feel like I am going to disappoint everyone around me. I am 22 years old, and I can't tell my friends or family that I spend my days changing nappies. I have a shit job, and my wife is a public servant, so I depend on her. I hate it, and it very much affects my mood every day...}

This identification with conservative Islam is a "moderate" response to the decades-long isolation and discrimination in the banlieues. While ethnic ties provide young people with security, on many occasions, they also prevent them from prospering or managing their dual membership in a balanced way.

\section{Indigenous Self-identification}

Social, ethnic, racial, and social identification get built differently when it is a minority seeking a new way of understanding belonging and cultural adaptation. This is the case for youth who have often achieved university studies and have a parcour of civic and political participation and involvement in ethnic, political, and anti-Islamophobia associations. They want to avoid making the same mistakes as the Beur generation (leaders of the first anti-racist movement in the 1980s) (Eseverri-Mayer, 2017). According to the youth, the latter's 
instrumentalization by the Socialist Party and the lack of recognition of ethnic and religious diversity have turned these activists into "puppets of power." This new elite represents $8 \%$ of the sample (6 of the young people interviewed) and fights for emancipation from the white and mainstream politics.

They define themselves as opposed to "secular Muslims" and mainstream feminism, calling for an intersectional movement that implies fighting for Muslim women's rights living in poor areas. They also distance themselves from young people who identify with conservative Islam, defining themselves as progressives though they consider them allies in the political struggle. "At least they have re-appropriated their religion, instead of hiding as our parents did. It's a start!" says one activist from the Political Party of the Republic's Indigenous People.

They fight for their "race" to be re-appropriated, a taboo subject in France, and recognized as a stigmatized and exploited racial minority. They believe the relations of domination during colonialism are getting reproduced today. "We are the underclass of society, below the poorest white workers; why don't politicians want to recognize it?" They want to choose their options and not depend on the representation of "whites," which is why many of these organizations have been accused of "anti-white racism."

\begin{abstract}
Ifeel I am an Arab and a citizen. I feel like (District) 93 is a territory I know, where I have grown up, with people around me, a territory where we are stigmatized, attacked, but it is a territory... there is a common sense of belonging. (...) But I'm sure of it, that I live in a country that is still colonial, and even though whites talk about "the social issue," we believe there is also a racial and ethnic issue (...) And we can't just wait around for whites to say: "Look at those poor people, they need this and that." We are the ones who should be saying it, with our own words, with our own claims to what we want. But it is a brutal change of mentality. (...) When I let the Afro hair that I got from my mom's side grow out, my aunt... I was told to straighten it. Even when I did, it was really hard for me. I did it almost as a political protest. At work, they told me that it was not "tenue professionelle" (business attire) because it took up a lot of space. It was bothersome....
\end{abstract}

In this group, some women may or may not wear a hijab, and some may or may not practice Islam. They want to feel free in their belonging while in the public sphere. They fight to re-define the term laicité, returning to the principle of the law from 1905, which, according to them, is one of the primary causes of Islamophobia. They demand compatibility between this principle and racial and religious diversity in France, accusing elites of covering up racism and Islamophobia. For them, Islam does not constitute a barrier to taking part in society. On the contrary, faith is most often a source of motivation for engagement and showing solidarity.

I think the advantage we have is knowing who we are, who we want to be, and how we want to be. I think those are a very solid basis for withstanding so much pressure. We conceive secularism from the legal and historical perspective as a vector for protecting the freedom of conscience and religion. But they have warped it.... We encourage girls to study, go to university, get involved in society, and now society is the one rejecting them by banning the veil. It's crazy! And then they accuse us of being "communitarians," and they demonize us.... 
This Arab, indigenous, and Muslim self-identification being forged in Paris's most isolated neighborhoods is also feminist. Young women want to end the clichés associated with Muslim women and attain "a convergence of struggles," collaborating with mosques and religious groups, and LGTBQ+ Muslims and atheist Muslims. They stand for an Islamic feminism and denounce discrimination both inside and out of the ethnic group. For them, identity is multiple, complex, and dynamic, which means that insisting on defining and debating it is a way of training, taming, and reducing people into categories.

\section{As for me, I don't say I have any one identity, but rather several. And if I define what my identity is, by nature, I have to deny a part of it. To define one identity for all of Islam in France is even stupider.}

This new activism is unveiling French racism. The March against Islamophobia held in Paris on December 10, 2019, attended by over 13,000 people, is one of the first successful actions of this movement, one that started in the suburbs and is uniting young people who feel they are Muslims, Arabs and who denounce the mistreatment of the "indigenous people of the Republic." A very small minority of the sample studied in Les Bosquets identifies with this new movement.

\section{The Reactive Ethnicity}

Cultural adaptation gets more complicated for youths from families deficient in human and social capital and face the risk of a segregated environment (drugs, violence, and radicalization). This group represents $10 \%$ of the sample. Having left school before earning their 'A-levels,' they usually have problems entering the labor market or, when they do, often get temporary, unskilled work.

Some go to the mosque daily and get involved with secular associations. However, they combine their religious and social participation with their social life in the streets, spending time with friends and, in some cases, selling drugs or engaging in petty delinquent activity. They describe their life as being trapped in a disadvantaged world where exclusion is unavoidable: "here we are the Arabs and the Blacks. They put us in these Towers to not bother them, the French, I mean... ", says a young 19-year-old man whose grandparents arrived in France in the 1970s. They also see an internal division between "good Muslims" and "bad Muslims," those who deny their Muslimhood and those proud of it. For them, youths from Maghreb countries who pretend to "be French" are traitors.

We are Muslim and proud to be so. My parents had to hide to pray. We are tired of putting up with police abuse... humiliation. I don't feel French. France deceived me a long time ago. I'm Muslim or an Algerian Muslim. I took part in the riots in 2005 and would do so again today.

They reaffirm their religious and ethnic identification and justify this feeling by explaining their rejection of French identity. For them, the values of la Republique (liberté, egalité et fraternité) have become unreal, a fraud; French identity is the cause of rampant Islamophobia, urban segregation, and police abuse. The decline of French identity is apparent, and there is a lack of morality in families and society as a whole. The primary example being gay marriage (le marriage pour tous). 
I think if I had children, I wouldn't let them into a public school, where they treat them as if there were just one sex... I can't stand gays. If anyone in my family were gay, I would kill him, I swear.

Their most brutal experiences with discrimination have been with the police. The repressive orientation of the police since 2000, like group police interventions in the suburbs and the aftermath of the state of emergency following the 2015 attacks, which turned young men into perpetual suspects, has dramatically deteriorated their relationship with the police. In the SI session with the police, every male participant (7 in total) had experienced police abuse.

\begin{abstract}
I had problems with the police. It was in the media and everything. I was the victim of police abuse. I lived in Building 5 in Les Bosquets, and down the street, some young people were doing something or other... when they saw the police coming, they ran off. Then they went into the building and started knocking on doors. I was at home with my family watching, I remember, the France-Tunis game, and the police broke down our door. They looked at me and said: "We're taking this one!" They started pushing me down the stairs and hit me, my mother was yelling at them, and they were pushing my mother. They insulted me, beat me with a truncheon and then the same policeman who hit me said that I had hit him! They wanted to put me in jail for drug trafficking... I stayed at the police station for a week. I was already thinking: "It's over, I'm being held prisoner!
\end{abstract}

Luckily, a neighbor had used his mobile to record the abuse on the stairs, the case was covered in the media, and the young man managed to file a complaint against the police. This feeling of helplessness vis-à-vis the police institution, combined with difficulties entering the workforce and the crisis of belonging, adds to the isolation felt by these young people. They move between feelings of victimhood and rage, which affects them emotionally and brings sudden changes in their personality (Bouamana, 1992). This could be the case for young people who may end up getting radicalized by the mutual influence occurring within the peer group (Slootman \& Tillie, 2006) and through a leader, they meet on the internet or in the street ${ }^{8}$. Lacking personal or professional plans and unable to find the necessary support in the family, mosque, or local associations - in large part due to a lack of communication and coordination between these structures resulting from the state's inability to deal with religious matters - the most vulnerable youth get caught between two worlds that will not let them resolve that vacuum of belonging or the suffering produced by discrimination. The isolation of these youth and the non-existence of intercultural or inter-religious places where they might express their malaise makes their lives very tense and stressful, leading to the development of anger and resentment towards wider society.

In summary, while the assimilationist-identified youths tended to describe how people treat them correctly when they show that they have a "French lifestyle," the traditionalidentified youths tended to highlight their malaise about living between two divided worlds, the youth who develop a reactive ethnicity express feeling deceived by the French due to racism and discrimination and respond with anger and pride for their Muslim origins.

\footnotetext{
${ }^{8}$ See the story of young Assis in Urban Studies, 2019.
} 


\section{Youths in the barrio of San Cristobal: Between Immigrant, Hybrid and Local Self- identification}

\section{Immigrant Self-identification}

The recent arrivals (after age 5) represent $31 \%$ of the sample and felt strongly identified with their own or their parents' national origins. They tend to speak often of Morocco and claim to be in constant contact with their family and spend every summer in their village or town of origin. Some remember the migration experience very well and are much more aware of the opportunities that they started to benefit from once in Spain, remembering the social situation they had to endure in Morocco.

Where did your family live in Morocco? My family lived on the periphery of Casablanca. But it isn't like the periphery here!

What was it like?

Horrible... It was like a slum, with sheet-metal roof houses... We had to fetch the water from a container and sometimes it was dirty. I remember people eating out of the garbage, and people died from eating rotten food. I got beat in school if I didn't know the lesson by heart, they beat me... I think if my parents hadn't moved, I would have emigrated later anyway. Here I am still Moroccan, but I have a lot of things to do... I have a future.

They are young people who get married young (before age 25) compared to the second generations. Nevertheless, before "settling down," they want to take advantage of the training and leisure activities that Madrid has to offer.

I am here to make the most of it! I'm doing a cooking and hospitality course, and then I go out to party, I meet people, I get to know the city, like any young man in Madrid (laughs) (...) I go to the mosque from time to time, but I know that someday I will feel more prepared to go more often... probably when I have family

They are unaware of a new hybrid identification (Muslim and Spanish) because it is only possible to identify with traditional Islam, the one inherited from their parents and grandparents. This is an Islam that mixes religiosity and tradition. However, these young people face a dilemma when they have to choose between either furthering their studies after their compulsory education or starting to work and earning money and getting married. They generally hold true and loyal to the path set out by the community group. In the SI group dedicated to entrepreneurship, two young women (one who dreamed of becoming a nurse and the other, a hairdresser) spoke about the difficulties they faced in reconciling the two paths, in the end choosing one over the other

It is as if you betrayed your family... It is very difficult because you are going to suffer either way. I think you suffer less if you stay at home if you don't move out of the neighborhood. (...) It is true that I loved going to mid-level training; I've always dreamed of becoming a nurse, helping people, wearing a white uniform... (laughs). And besides, they let me wear a veil... a social educator went to talk to them. But I married 
my cousin, I am very much in love, eh (laughs) and we moved to another neighborhood, so that made it hard to go every day. But when my son grows up, I plan on continuing my training. I want to take advantage of it... I always want to learn, dammit, it's true!

I used to love hairdressing, making myself look pretty, making other girls pretty. I thought it'd be amazing to work, to have my own hair salon! But I've already decided, even though (the social educator) tried to convince me. What if no one else ever proposes to me and I stay single? I am afraid of not being able to have my house, my children... I don't think I'm wrong. I've even already seen the dress I'd like to wear in a magazine! (laughs) My parents will be very happy that day!

They generally keep ties to the ethnic group, do some training, or collaborate in local associations. Still, they never end up leaving the low qualified work niches into which their parents integrated. "I would've loved to go to university, but I got married, and having children makes it complicated. I belong to the AMPA (parent's school association) and ECYS (local association). I want to see my son's face every day when he gets out of school... and know what his teacher is like.... On the weekend, I take him to the M30 Mosque for classes in Arabic and values" (she says sadly). They project onto their children the dreams that they could not achieve. They want them to "do better than they did," while also believing in the need for passing down traditional Islam and reinforcing the ethnic bonds.

\section{Hybrid Self-identification}

This group of young people of Moroccan origin define themselves as Spanish and Muslim and represent 52\% of the sample, most of whom are women (36 of the 70 interviewees). These young people speak about their belonging in a hybrid sense and say they represent the new Spanish-Muslim generation. They have grown up in an environment with great ethnic diversity. One made up of Latin American communities (from Ecuador, Colombia, the Dominican Republic, Bolivia, Peru, etc.), gypsy communities (relocated to this urban territory in the 1980s), communities from eastern Europe (from Romania mainly), and the Spanish community (which is still the majority). As demonstrated in other publications (EseverriMayer, 2019), young people of Moroccan origin feel Muslim. Simultaneously, they move, speak, and even dance like Latin Americans, acquire "gypsy" expressions, and know the Spanish's cultural relational codes perfectly.

Feeling Muslim is above national identity. I don't believe in borders. But I also feel very Spanish. We have taken on a lot of Spanish culture. I speak Spanish with my sisters, we watch TV, sing Spanish songs... We don't celebrate Christmas, but I love it! The lights! The sweets! The paella! The Spanish tortilla! (laughs) You just take on everything. (...) In the neighborhood, we sing flamenco with the gypsies, we clap our hands, and then we dance reggaeton with the Latinos. Then I have Spanish friends. I have had more male Spanish friends than Muslim male friends, I swear! We are a mix. Did you know that in this neighborhood? There are more than 40 different cultures!

The wishes of these young people are different from those of young people who selfidentified as immigrants. They seek to build a hybrid space where their multiple identities can 
find expression and work together in the public space. They refuse to be stigmatized as immigrants or as religious believers only. The new Spanish Muslim generation wants to be able to practice their religion freely and bond with their family through traditions. Still, they also insist on being in the mainstream, partaking in urban initiatives, and participating at a local level. The tightly-knit network of associations and actions of civil society in the San Cristóbal neighborhood (Eseverri-Mayer, 2015), inherited from the Madrid neighborhood movement of the 1970s, fosters involvement among these new generations in community-based activities. As was the case in the banlieues of Paris in the 1980 and the 1990s (Bouamama, 1990; Dubet, 1982), young people in San Cristóbal are fundamental to carrying out associative and neighborhood activities, organizing local festivities, supporting the elderly, helping distribute food during the economic crisis, etc. In this associative environment, young people find spaces in which to express their double belonging.

The association was where I could be myself, without being afraid of telling the world I am Muslim, and I felt comfortable because I was with other girls and boys like me who felt Spanish and did not deny either one of their two identities. Sometimes in high school, I would get together with other kinds of girls who were much more, you know, they really leaned more toward the Moroccan identity of their parents, of origin, you know? But I wasn't so sure about that, because I said: "I am aware of my origins, aware of where my parents come from, aware they are immigrants, that they come from Morocco, but I was born in Madrid! I've never lived anywhere other than Spain! So, it was hard for me... I said I was Moroccan to please people who felt that way... of course, because then there is that other side where it's like if you don't say you are Moroccan, it looks like you're denying something... you have to defend yourself against the other (the Spanish) ...

Young people from this new generation shy away from any obligation to be loyal and instead adopt a mixed belonging, extolling their Muslimhood - distancing themselves from traditionalism and new conservatism - and wanting to discover true Islam, to study it and go to its sources, to separate religion and spirituality from dogma and tradition. They also want to do away with the "gossip" and stigmatization that this tradition holds towards certain groups, such as women or homosexuals. Many women participating in the SI and interviewed in the second phase of the research spoke about an Islamic feminism that would come to defend the original Islam. This is youth seeking out a more authentic Islam, one more faithful to the revealed message.

I used to see my parents pray, but in reality, my parents have never spoken to me directly about Islam (...) In Islam, they say women have more rights than men, and we need that feminism because we need that interpretation, not because there is fundamental inequality in the Koran, but this kind of feminism explains Islam as it is. Islam has been explained by mostly men, and it is time for a woman to take over, I'd say, wouldn't you? In the Arab world and in Morocco, people lack knowledge about Islam. They just don't know that there are differences. I talk to my mother about the different schools of thought, and she just says: what are you talking about? And for them, it is black or white, and for certain people, what prevails is tradition. I give them my explanation, my argumentation, and they generally let me do what I 
want. But you have to get them to use reason because they have grown up with those ideas.

Consequently, these young people want to rebuild Muslim belonging by projecting it positively, as a healthy way of life compatible with Spanish values. Far from hindering integration, this new hybrid self-identification becomes a vector of upward mobility and participation for these young people.

\section{Neighborhood Self-identification}

Young people from the second generation and the 1.5 generation (arrived in Spain before the age of 5) living in a disorganized state of affairs, having dropped out of the educational system and unable to integrate into the labor market. These make up $17 \%$ of the sample. Their parents' working conditions (a combination of instability and precariousness, with endless hours) and low human capital impede their progress. They live a kind of "experience in limbo", which does not entail a total disconnection from society, but rather an experience of vulnerability or disaffiliation (Castel, 1995). They live in an intermediate state, enrolled in vocational training programs but not regularly attending classes; holding a temporary job, but still depending on the family; and committing petty crimes without being hardened criminals. They are "in no man's land" (Eseverri-Mayer, 2015), living between two worlds. One integrated world, in touch with friends who study or social educators and neighbors. And one street world, which ties them to harmful social capital, peer groups living on the street, and carrying out petty crime (mainly soft drug trafficking and theft).

This is a social segment that still feels Moroccan, but who is also starting to define themselves as Muslim and who feel like they are "from San Cristóbal," proud to be from that neighborhood and part of the working-class. Furthermore, these young people reject the way of life of their parents, dream of a better future, and at the same time denounce the racism and discrimination they endure. The post-9/11 world, especially the climate of suspicion toward young people of Moroccan origin since the attacks in Madrid (March 2004) and Barcelona (August 2017), play a determining role.

When I get on the subway wearing a headscarf, I get a lot of looks. Like they're looking at something weird, I don't know... Many times, I have taken off my headscarf on the subway because people look at me a lot. I think it's like... you scare me! Like maybe you've got a bomb in your bag! And in the neighborhood, it's no big deal. No one has ever said anything. It's like I'm at home here (laughs). It's only outside when you might get a look like that. One day leaving work and walking down the street, I put on my headscarf, I came across a Spanish woman, and she said: take it off, take it off, take it off! And like moving away from me.

On the subway is the worst... You can see fear in people's eyes. They look at you up and down, look at your backpack as though you might be carrying a bomb. But you really notice it with the police. Ever since those attacks, they always stop you, without fail, asking for papers, papers, every day. Even if it's the same officer, every day, they stop you! Sometimes it makes you want to say, "Dude, don't you know me already?" Besides, it's not like by asking you for your papers, they will somehow know if you are making bombs, right? (laughs)". 
However, the ties between the police and youth in San Cristóbal have not completely broken down as they have in Les Bosquets. Young people in San Cristóbal do not say they distrust and fear the police. Though surveillance is an everyday occurrence, police interventions are not group-based, and young people do not report harassment or violent experiences. There are still police dedicated exclusively to prevention, such as the local police and youth agents (agentes tutores). Regarding the latter, their treatment and familiarity are valued - "they are like the neighborhood policemen" - as is their spirit of dialogue and helping neighbors. The youth agents invited to the SI session explain that their goal is more preventive; they work more as mediators than as repressors, an essential difference concerning Les Bosquets. Despite this, the youth report recurring experiences of discrimination with the national police, such as this young woman working as a waitress.

One day I got attacked in the restaurant where I work, some girl with a knife and I got cut on one hand. An ambulance came, they dressed the wound, and then the national police came. One of them asked for my ID, and I gave it to him. Then he said: "ah, so you are a Moor!" That bothered me, you know because if I give you a Spanish ID card, it's because I'm Spanish and there's no reason for you to go and tell me that I'm a Moor.... It's totally out of line!

On the other hand, these young people also start practicing Islam as a form of "rehabilitation" (in the sense given by Khosrokhavar, 1998). Religion and attending mosque provide order to their lives, a new outlook that might lead to getting a new job or getting married and starting a family. Unlike the Spanish Muslims, this group does not seek Islam's essence, but rather it serves as a guide telling them what is allowed (halal) and what is prohibited (haram), just as it does for the young people in Les Bosquets. As Moreras (2018) points out, they replace one model of conservatism for another. This is no longer an Islam rooted in family and seeking to pass on and protect cultural baggage from one generation to the next. Young people break away from this family-based model and adopt a new kind of conservatism, one that vindicates Muslim uniqueness and gives them security, daily guidelines, and dignity. Because they find no references and do not understand the hired imams (usually from Egypt) in the mosque, they follow Islamic preachers on social networks, watch didactic videos about Islam on YouTube and follow the example of how to behave and live from religious people in the neighborhood. They are proud of their Islam and stand up for their difference, claiming time and again that Islam is the ultimate religion and, therefore, "the one and only." There is no longer that element of subordination that came with immigrant Islam. Instead, young people rebel against this submission and stand up for their "active and proud presence as Muslims" (Moreras, 2018, p. 35). One young man from San Cristóbal describes his identification this way.

I am a Muslim, but I am not a Muslim because my parents are Muslim. My father taught me the Koran from a young age. He taught me how to study it. He sometimes went so far as to beat me into learning it... And that doesn't seem right to me (...) It's like the mosque here, I go to the mosque, and they start speaking Arabic, but I don't know what they're saying, I don't understand the imam ... so now I want to understand and practice it knowing, so I listen to people on Facebook and follow some preachers on Instagram who explain the suras, and what can and cannot be done, which helps you lead a more orderly life... It settles me down..... 
Research in the San Cristóbal neighborhood indicates that these young people are not currently developing a reactive ethnicity (hateful discourse contrary to the majority Spanish population). This is largely due to the ethnic diversity of the surroundings and civil society's capacity to include these young people in participatory processes. Thanks to this, these vulnerable young people also develop a "feeling of neighborhood pride" that identifies them with a social class of working people from different origins struggling together. This neighborhood pride projects two images: a negative image associated with poverty, marginality, physical degradation of the buildings, and insecurity or crime, and another positive image that focuses on neighborhood solidarity, the union, and mobilization of residents in difficult times. For the moment, this positive image fosters the development of an emotional attachment to the neighborhood, which helps in coping with the suffering that accompanies negative living conditions. This local belonging is not incompatible with Muslim self-identification. They can be proud of both.

\begin{abstract}
I feel like I'm from San Cris... not Madrid because when I go to the city center or Lavapies, I have a good time, but after a while, I say: "What am I doing here? I'm going home, to my neighborhood! Which is where I feel safe. It's funny, everyone is afraid of going to San Cristóbal, and nowadays that's where I feel safe. Not even the couriers go there. They say it is a really dangerous neighborhood, the Bronx! But those are my people, people from all over, blacks, Moors, Latinos, Gypsies, Spaniards... there's something from everywhere, humble, hard-working people, people breaking their backs to get ahead and fighting for the others. That is San Cris. I am Moorish, Moroccan (laughs), Muslim, and also from San Cris!
\end{abstract}

\title{
Conclusions
}

Ethnic, racial, and social relations in France and Spain have been changing in recent years. The role of the second generations from disadvantaged areas within this evolution is being decisive. This research has shown how race, religion and ethnicity influence youth sense of belonging. However, above all, it demonstrates how social class (urban segregation), Islamophobia and the lack of ethnic diversity and civic participation clearly determine their feelings and self-identification. In Paris, urban segregation circumscribes Islamophobia and lack of participation reinforce isolation and sentiment of abandon from the mainstream. On the contrary, in Madrid, ethnic diversity and local implication reduce negative effects of discrimination and encourage belonging to the mainstream society.

In Les Bosquets (Paris), the laïc self-identification "a la française" - though commonplace in the 1980s and 1990s - is significantly less widespread today. It has been replaced by a new, proud, conservative Islam (represented by more than a half of the sample), one that dissociates itself from the family's ethnicity and legacy (Eseverri-Mayer, 2019; Jacobsen, 1997; Mushaben, 2008; O’Toole \& Gale, 2010). Furthermore, this change creates new polarization between this group how want to stay loyal to this new conservative Islam as a way of defending themselves from the increasing Islamophobia and those who don't want to fall into the "victimhood narrative" and still define themselves as laic and French. This polarization differs from the situation of the second generation in others European countries, Canada and the United States (Bastug, 2020). This outlying Parisian neighborhood underline French specificity and show the inverse situation of what Waters (1994) observed in New York. Ties to the ethnic group do not build greater trust towards young people or foster their integration and social mobility. 
On the contrary, young people who take refuge in conservative Islam find new support, but from the moment that this kind of belonging is judged negatively in French society and the young people get singled out and stigmatized for it, this new way of self-identifying loses its capacity for integration. A situation that enhances conservatism. Unlike in New York, those who assimilate more quickly to a French way of life are the most widely accepted and the ones who leave the neighborhood, moving up the social ladder. This differs from the case of New York, where stressing an ethnic identification in a segregated context is not judged as "acting white," as Waters explains. Quite the contrary: acting like "a Frenchman" means acting like "a white," no longer being loyal and faithful to the ethnic and religious group.

In this context of rejection of Muslimness, selective acculturation (Portes \& Rumbaut, 2001) or integration strategies (Berry, 1980) — which represent the main acculturation strategy of the second generation internationally (Barwick \& Beaman, 2019; Beaman, 2017; Berry \& Hou, 2017; Crul \& Thomson, 2007; Portes et al., 2016) - in Les Bosquets it reduces to a minority. It is only represented by young activists who empower themselves by defining themselves as "racialized" and "indigenous" citizens, breaking the French taboo on race and denouncing how the descendants of colonialism represent the new underclass. Likewise, a space is opened up for a reactive ethnicity to emerge, isolating a very minor (though no less important) part of young people who feel deep anger and injustice towards the institutions (symbolized by police brutality) of the Republic.

On the other hand, in the context of San Cristóbal, the young people living "in no man's land" and starting to identify with conservative Islam are not developing a reactive ethnicity. The main reasons for this are the ethnic diversity of the neighborhood, the absence of institutionalized Islamophobia, and civil society's capacity for including them in the processes of social-class belonging and neighborhood participation, something that occurred in the French suburbs in the 1980s-90s as documented by Pierre Bourdieu (1993) in La Misère du Monde. Young people in Madrid are also influenced by a new, more conservative Islam while simultaneously identifying with, and feeling proud of, their neighborhood thanks to associative networks that do not neglect or reject them as they do in Paris. Instead, these civic networks allow them to share their social status and religious and ethnic specificities with their neighbors of Latin origin or European origin. Thus, the optimism of the surveys conducted by Portes et al., (2016) in Spain is confirmed upon discovering that the majority of the North African second generations (half of the sample) identified as hybrid and see no contradiction between Islam and local and national belonging. The young people distance themselves from traditional Islam (ethnic and family-based) and conservative Islam (belonging to the new Saudi Arabian theologies), instead expressing their double identification in shared areas of participation. Furthermore, immigration in Spain is a young and recent phenomenon, so self-identifying as immigrants among newcomers is still significant ( $31 \%$ of the sample).

The future of these different types of self-identification will largely depend on the evolution of Islamophobia in the two contexts and on the potential influence of extremist political parties such as the National Front in France and VOX in Spain. The emerging activism developed by civil society (Muslim and non-Muslim) in these disadvantaged settings will also be decisive. Especially in Paris, young people need to open up a new political space that will allow them to denounce urban isolation and ethnic concentration and to express their right to feel that they are Arab and Muslim, and at the same time, citizens of France.

\section{Funding Details}

This work was funded by the Spanish Ministry of Science and Innovation (Project reference: RTI2018-095283-J-I00), the European Union, Research Executive Agency under the Grant "Intra European Fellowships (IEF), Grant Agreement Number: 328675 and the BBVA Foundation, under the Grant Leonardo Fellowship. 


\section{Disclosure Statement}

I want to acknowledge the Spanish Ministry of Science and Innovation (Project reference: RTI2018-095283-J-I00), the European Commission, the BBVA Foundation for allowing me to be present and get unique contact with the future European generations of NorthAfrican origin.

\section{References}

Abdellali, A \& Mohammed, M. (2016). Islamophobia. La Découverte.

Alba, R. \& Waters, M. (2011). The next generation: Immigrant youth in a comparative perspective. New York University Press.

Ayuntamiento de Madrid (2017) Paro registrado por barrios a 1 de Enero de 2016. Subdirección General de Estadística.

Barou, J. (2014). Integration of Immigrants in France. A Historical Perspective". Identities: Global Studies in Culture and Power, 21 (6), 642-57.

Barwick, Ch. \& Beaman, J. (2019). Living for the neighborhood: Marginalization and belonging for the second-generation in Berlin and Paris. Comparative Migration Studies, 7(1), 4-17. https://doi.org/10.1186/s40878-018-0105-3

Bastug, M. F. (2020). Senses of Belonging and Identity within North American Turkish Diaspora in the post-9/11 Era. American Journal of Qualitative Research, 4(1), 1-15. https://doi.org/10.29333/ajqr/7841

Beaman, J. (2017). Citizen outsider: Children of North African immigrants in France. University of California Press.

Berry, J. W. \& Hou, F. (2017). Acculturation, discrimination and wellbeing among second generation of immigrants in Canada. International Journal of Intercultural Relations, 61, 29-39. https://doi.org/10.1016/j.ijintrel.2017.08.003

Berry, J. W., Phinney, J. S., Sam, D. L., \& Vedder, P. (2006). Immigrant youth: Acculturation, identity, and adaptation. Applied Psychology, 3(55), 303-332. https://doi.org/10.1111/j.1464-0597.2006.00256.x

Berry, J.W. (1980) Acculturation as varieties of adaptation. In Padilla, A., (Ed.), Acculturation: Theory, Models and Findings, (pp. 9-25). Westview, Boulder.

Bertaux, D. (1980). L'approche biographique: Sa validité méthodologique, ses potentialités [The biographical approach: Its methodological validity, its potential]. Cahiers Internationaux de Sociologie, 69, 197-225. https://www.jstor.org/stable/40689912

Bouamama, S. (1990). La citoyenneté dans tous ses états: De immigration à la nouvelle citoyenneté. L'Harmattan.

Bourdieu, P. (1979). La distinction: Critique social du jugement [The distinction: Social critique of judgment]. Editions Minuit.

Bourdieu, P. (1993). La misère du monde [The misery of the world]. Points.

Brubaker, R. (2001). Au-delà de l'identité [Beyond identity]. Actes de Recherche en Sciences Sociales, 4(139), 66-85. https://www.persee.fr/doc/arss_0335-5322_2001_num_ 139_1_3508

Castel, R. (1995) La métamorphose de la question sociale, Une chronique du salariat. Fayard.

Castells, M. (2005). La era de la información. Economía, sociedad y cultura (Vol 2). El poder de la identidad [The age of information. Economy, society and culture (Vol 2). The power of identity]. Alianza Editorial.

Chacal, E. (2015). A divided republic nation, state and citizenship in contemporary France. Cambridge University Press. 
Creswell, J. W. (2007). Qualitative inquiry \& research design. Choosing among five approaches. Sage Publications.

Crul, M. \& Mollenkopf, J. (2012). The changing face of world cities: Young adult children of immigrants in Europe and the United States. Rasel Sage Foundation.

Crul, M. Schneider, J. \& Leslie, F. (2012). The European second generation compared: Does the integration context matter? Amsterdam University Press.

Crul, M., \& Thomson, M. (2007). The second generation in Europe and the United States: How is the transatlantic debate relevant for further research on the European second generation? Journal of Ethnic \& Migration Studies 33(7), 1025-1041. https://doi.org/10.1080/13691830701541556

Denzin, N. K. \& Lincon, Y. S. (2011) The SAGE Handbook of Qualitative Research. Sage.

Drouhot, L. G. \& Nee, V. (2019). Assimilation and the second generation in Europe and America: Blending and segregating social dynamics between immigrants and natives. Annual Review of Sociology, 45, 177-199.

Dubet, F. (1982). La galère. Jeunes en survie [A hard time. Survival youth]. Persée.

Eseverri-Mayer, C. (2015). Jóvenes en tierra de nadie. CIS.

Eseverri-Mayer, C. (2017). Construyendo pertenencias: Hijos y nietos de inmigrantes en los suburbios de Madrid y París. Anuario de la inmigración en España, 12(2017), 276-295. https://doi.org/10.24241/AnuarioCIDOBInmi.2017.276

Eseverri-Mayer, C. (2019). Linking suburban youth in Madrid and Paris. The role of civil society structures in the integration of children from Muslim backgrounds. Urban Studies, 56(13), 2616-2634. https://doi.org/10.1177/0042098018801160

Eseverri-Mayer; C. (2007). La "revuelta urbana" de los hijos de inmigrantes en Francia. Migraciones Internacionales, 4(2), 189-200.

Gebhardt, D., Zapata-Barrero, R. \& Bria, V. E. (2017). Trayectorias de jóvenes de origen diverso en Barcelona. Explorando tendencias y patrones [Trajectories of youth of diverse origin in Barcelona. Exploring trends and patterns]. GRITIM-UPF Policy Series 5. Barcelona. Pompeu Fabra University.

Glaser, B. \& Strauss A. (1967). The discovery of grounded theory. Strategies for qualitative research. Sociology Press.

Gurer, C. (2019). Refugee Perspectives on Integration in Germany. American Journal of Qualitative Research, 3(2), 52-70. https://doi.org/10.29333/ajqr/6433

Jacobson, J (2010). Islamic traditions and Muslim youth in Norway. Brill.

Jacobson, J. (1997). Religion and ethnicity: Dual and alternative sources of identity among young British Pakistanis. Ethnic \& Racial Studies, 20(2), 238-56. https://doi.org/10.1080/01419870.1997.9993960

Jencks, C. \& Mayer, S. (1990). The social consequences of growing up in a poor neighborhood. In L. M. McGeary \& L. Lynn (Eds.), Concentrated urban poverty in America (pp. 111186). National Academy.

Keaton, D. (2010). The politics of race-blindness: (Anti) Blackness and category-blindness in contemporary France. Du Bois Review: Social Science Research on Race, 7(1), 103-31. https://doi.org/10.1017/S1742058X10000202

Kepel. G. (1987). Les banlieues de l'Islam. Naissance d'une religion en France. Gallimar.

Khosrokhavar, F. (1998). L'islam des jeunes [Youth Islam]. Persée.

Madonia, S. (2018). Musulmanes, jóvenes y ciudadanos. Un estudio etnográfico en la Comunidad de Madrid. CSIC.

Moreras, J. (2018). Identidades a la intemperie. Una mirada antropológica a la radicalización en Europa [Identities in the open. An anthropological look at radicalization in Europe]. Ediciones Bellaterra. 
Mushaben, J. M. (2008). Gender, hiphop and pop-Islam: The urban identities of Muslim youth in Germany. Citizenship Studies, 12(5), 507-526. https://doi.org/10.1080/ 13621020802337931

Mythen, G. (2012). Identities in the third space? Solidity, elasticity and resilience amongst young British Pakistani Muslim. The British Journal of Sociology, 63(3), 393-411.

O'Toole, T. \& Gale, G. (2010). Contemporary grammars of political action among ethnic minority young activists. Ethnic \& Racial Studies, 33(1), 126-143. https://doi.org/10.1080/01419870903118122

Park, R. E. \& Burgess, E. W. (1925). The city. The University of Chicago Press.

Pégram, S. (2020). Pris pour cible dans la banlieue: Self-identity, language maintenance, racism and exclusion amongst African youths in the Paris suburbs. Ethnicities, 20(1), 93-114.

Pikety, Th. (2019). Capital et idéologie [Capital and ideology]. Seuil.

Portes, A. \& Rumbaut, R. (2001). Legacies: The story of the immigrant second generation. University of California Press.

Portes, A. \& Zhou, M. (1993). The new second generation: Segmented assimilation and its variants. The ANNALS of the American Academy of Political and Social Science, 530(1), 74-96. https://doi.org/10.1177/0002716293530001006

Portes, A. Aparicio, R. \& Wickstrom (2013). Coming of age in Spain: The self-identification, beliefs, and self-esteem of the second-generation. British Journal of Sociology, 62(3), 387-417. https://doi.org/10.1111/j.1468-4446.2011.01371.x

Portes, A. Aparicio, R. \& Wickstrom, E. (2016). Spanish legacies. The coming of age of the second generation. University of California Press.

Portes, A. Aparicio, R. \& Wickstrom, E. (2018). Hacerse adulto en España: La integración de los hijos de los inmigrantes. Anuario CIDOB de la Inmigración 2018, Noviembre. 148181. https://doi.org/10.24241/AnuarioCIDOBInmi.2018.148

Roy, O. (2009). Secularism confronts Islam. Columbia University Press.

Roy. O. (2006). L'Islam de France. Confluences Méditerranée, 2, 49-55.

Simon, P. Beauchemin, C. \& Hamel, Ch. (2018). Trajectories and origins: Survey on the diversity of the French population. Springer.

Slootman, M. \& Tillie, J. (2006). Processes of radicalisation. Why some Amsterdam Muslims become radicals. IMES.

Téllez, V. \& Madonia, S. (2018). Visibilizing 'invisibilized' Spanish Muslim youth. In Planet, A. (Ed.) Observing Islam in Spain contemporary politics and social dynamics (pp. 113139), Muslim Minorities, 28(2008).

Touraine, A. (1965). Sociologie de l'action [Sociology of action]. Seuil.

Touraine, A. (1978). La voix et le regard [The voice and the look]. Seuil.

Tribalat, M. (2010). Les yeux grand fermés. L'immigration en France [Eyes wide closed. Immigration to France]. Denoël.

Veredas, S. (2011) "Identidad étnica y de género entre adolescentes de origen marroquí". Papers. 97(1), 117-144. http://dx.doi.org/10.5565/rev/papers/v96n1.161

Wacquant, L (2008) Urban Outcasts: A Comparative Sociology of Advanced Marginality. Polity.

Waters, M. (1990). Ethnic options: Choosing identities in America. University of California Press.

Waters, M. (1994). Ethnic and racial identities of second-generation Black immigrants in New York City. International Migration Review, 28(4), 795-820. https://doi.org/10.2307/2547158

Wihtol de Wenden, C. \& Leveau, D. (2001). La Beurgeoisie: Les trois âges du mouvement associatif civique issu de l'immigration [La Beurgeoisie: The three ages of civic associative movement resulting from immigration]. CNRS Éditions. 


\section{Notes on Contributor}

Cecilia Eseverri-Mayer is a professor at the Complutense University of Madrid and currently heads a project aimed at preventing violent extremism (CIVIL PREVENT) in Spain. She carried out intense ethnographic work in disadvantaged urban areas in Madrid, Paris and London. This experience has given her a unique insight into migration and youth studies, urban conflict and poverty, and ethnic and religious relations. She was a Marie Curie fellow (from 2013 to 2015) at the École des Hautes Études (Paris) and was also the recipient of a BBVA Leonardo Grant (2017-2019). Her work has been published in a variety of international journals. 